\title{
The Effect of Hydroxyurea in Sickle Cell Disease Patients
}

\author{
Dr.Spvittal ${ }^{1}$,Dr.Mir Firman Ali $^{2}$,Dr.C.Ramakrishna ${ }^{3}$, \\ Mr.B.Venkateswar Rao ${ }^{4}$ \\ ${ }^{1}$ Assistant Professor,Department Of Internal Medicine,Prince Saud Binjalawy Hospital,King Faisal \\ University,Alahsa \\ 2. Assistant Professor,Department Of Biochemistry, NRIIMS, Sangivalasa, Visakhapatnam,India \\ ${ }^{3}$ Assistant Professor Department Of Biochemistry, NRIIMS,Sangivalasa, Visakhapatnam,India \\ ${ }^{4}$.Statistitian, NRIIMS,Sangivalasa,Visakhapatnam,India
}

\begin{abstract}
Aim: To know the effect of hydroxyurea in sickle cell disease patients by measuring the HbF levels. Materials and Methods: 50 patients suffering from sickle cell disease were taken from Prince Saud Bin Jalavy Hospital, Alahsa. The HbF levels were monitored in these patients before and after 4 months of administration of hydroxyurea. The HbF were monitored using Hb Electrophoresis.

Observation: The mean difference was - 0.3979 with $S D$ of 0.0663 , standard error 0.0094 and $t$ value $0 f-42.32$ and $p$ value of $p<0.0001$

Conclusion: In all patients there was 20-25\% of improvement of fetal Hb after 4 months of treatment with hydroxyurea.
\end{abstract}

Keywords: Sickle cell disease $\mathrm{HbF}$, Hydroxyurea

\section{Introduction}

Sickle cell disease in a chronic condition and a sinister haemoglobinopathy with serious consequences and high mortality ${ }^{1}$.The median age survival of $14.3 \mathrm{yrs}$, with $20 \%$ deaths occurring in first 2 yrs of life,one third occurring before the fifth year of life,half between 5 and $30 \mathrm{yrs}$ age and one sixth after the age of $30^{2} \mathrm{It}$ is caused due to substitution of glutamic acid by valine in the sixth position ${ }^{3}$. This results in the cell having sickle shaped cells with subsequent consequences of polymerization of RBC and finally sickle cell crises(pain,thrombosis,infection) ${ }^{4,5} \cdot \mathrm{HbF}$ is one of the types of hemoglobin seen in late foetal life ${ }^{6}$.Hydroxyurea is an anticancer drug which acts by neutralizing the tyrosyl free radicals and there by inhibiting the enzyme ribonucleotide reductase ${ }^{7}$.Electrophresis is the separation of charged particles by administration of electric current $^{8}$.

\section{Materials And Methods}

Fifty patients suffering from sickle cell desease from Prince Saud Bin Jalawy Hospital were taken.HbF levels were monitored before and after administration of hydroxyurea.The $\mathrm{HbF}$ levels were monitored using $\mathrm{Hb}$ Electrophoresis.All necessary norms were taken in informing the Ethics Committee.

\section{Inclusion Criteria-}

1.Age group 15-45 yrs including both male and female patients.

2.Sickle Cell Anaemia patients showing electrophretic patterns of of $\mathrm{HbS}, \mathrm{F}, \mathrm{A}_{2}$, and A only.

\section{Exclusion Criteria-}

1.AST $>100 \mathrm{IU} / \mathrm{L}$

2.Albumin $<3 \mathrm{gms} / \mathrm{dl}$

3.Sr.Creatinine $>2 \mathrm{mg} / \mathrm{dl}$

$\mathrm{The} \mathrm{HbF}$ levels were monitored using $\mathrm{Hb}$ Electrophoresis.

Statistical Analysis-Statistical Analysis was done usin paired ' $t$ ' Test. 


\section{Results}

I) Parameters of paired 't ' test:

1. Sample size $(\mathrm{n}) \quad=\quad 50$

2. Mean difference $=-0.3979$

3. Standard deviation $=0.0663$

4. Standard Error $=0.0094$

5. $\mathrm{t}$ value $=\quad-42.32$

6. $\mathrm{P}$ value $=\quad \mathrm{P}<0.0001$

7. Degrees of freedom $=49$

8. $95 \%$ confidence intervals $=-0.416790$ to -0.379010

Table No. 1 Showing $\mathrm{Hb} \%$ levels of Subjects on admission and after 4 months: $(\mathrm{n}=50)$

\begin{tabular}{|cc|l|l|}
\hline $\mathrm{Hb}$ \% Class Interval & $\mathrm{Hb} \%$ On admission & $\mathrm{Hb} \%$ After 4 months \\
\hline 1. & 1.5 & $(22.00)$ & 00 \\
& $2.5-2.0$ & 35 & $(0.00)$ \\
\hline $2 . \quad 2.0-2.5$ & $(70.00)$ & 21 \\
& 04 & $(42.00)$ \\
\hline 3. & $(08.00)$ & 27 \\
& 00 & $(54.00)$ \\
\hline $4 . \quad>2.5$ & $(0.00)$ & 02 \\
& 50 & $(04.00)$ \\
\hline Total & $(100.0)$ & 50 \\
& & $(100.0)$ \\
\hline
\end{tabular}

- It is observed from the data that $48 \%$ of beneficiary has shown increase of $\mathrm{Hb} \%$ level 2.0-2.5 range and 4 $\%$ of them also shown increase of $\mathrm{Hb} \%$ level of $>2.5$.

Fig-1

Comparisson in HbF Levels Before and After 4 Months of Hydroxurea

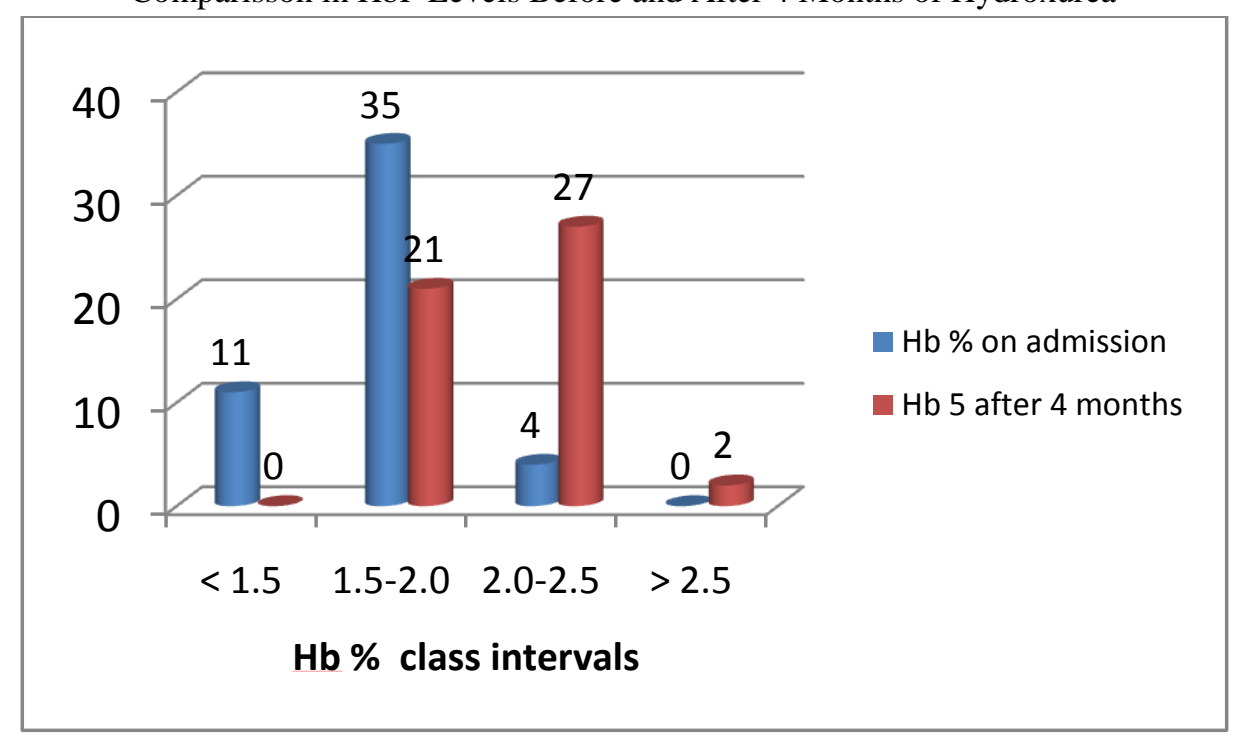

II) Parameters of paired ' $t$ ' test: (Male beneficiary)

1. Sample size $(\mathrm{n}) \quad=30$

2. Mean difference $=-0.4087$

3. Standard deviation $=0.075$

4. Standard Error $\quad=0.0137$

5. $\mathrm{t}$ value $=-29.73$

6. $\mathrm{P}$ value $=\mathrm{P}<0.0001$

7. Degrees of freedom $=29$

8. $95 \%$ confidence intervals $=-0436720$ to -0.380680 
No 2 Distribution $\mathrm{Hb} \%$ levels in male subjects $(n=30)$

\begin{tabular}{|c|c|c|}
\hline $\mathrm{Hb} \%$ Class Interval & $\mathrm{Hb} \%$ On admission & $\mathrm{Hb} \%$ After 4 months \\
\hline $\begin{array}{ll}1 . & 1.5\end{array}$ & $\begin{array}{l}06 \\
(20.00)\end{array}$ & $\begin{array}{l}00 \\
(0.00)\end{array}$ \\
\hline 2. $1.5-2.0$ & $\begin{array}{l}21 \\
(70.00)\end{array}$ & $\begin{array}{l}12 \\
(40.00)\end{array}$ \\
\hline 3. $2.0-2.5$ & $\begin{array}{l}03 \\
(10.00)\end{array}$ & $\begin{array}{l}16 \\
(53.33)\end{array}$ \\
\hline 4. $>2.5$ & $\begin{array}{l}00 \\
(0.00)\end{array}$ & $\begin{array}{l}02 \\
(6.67)\end{array}$ \\
\hline Total & $\begin{array}{l}30 \\
(100.0)\end{array}$ & $\begin{array}{l}30 \\
(100.0)\end{array}$ \\
\hline
\end{tabular}

- It is observed that $43.33 \%$ of benefices had shown increase in Hb \% $2.0-2.5$ group followed by 6.67 $\%$ increase in $>2.5$ group.

Fig-2

Comparisson in HbF Levels Before and After 4 Months of Hydroxurea in Males

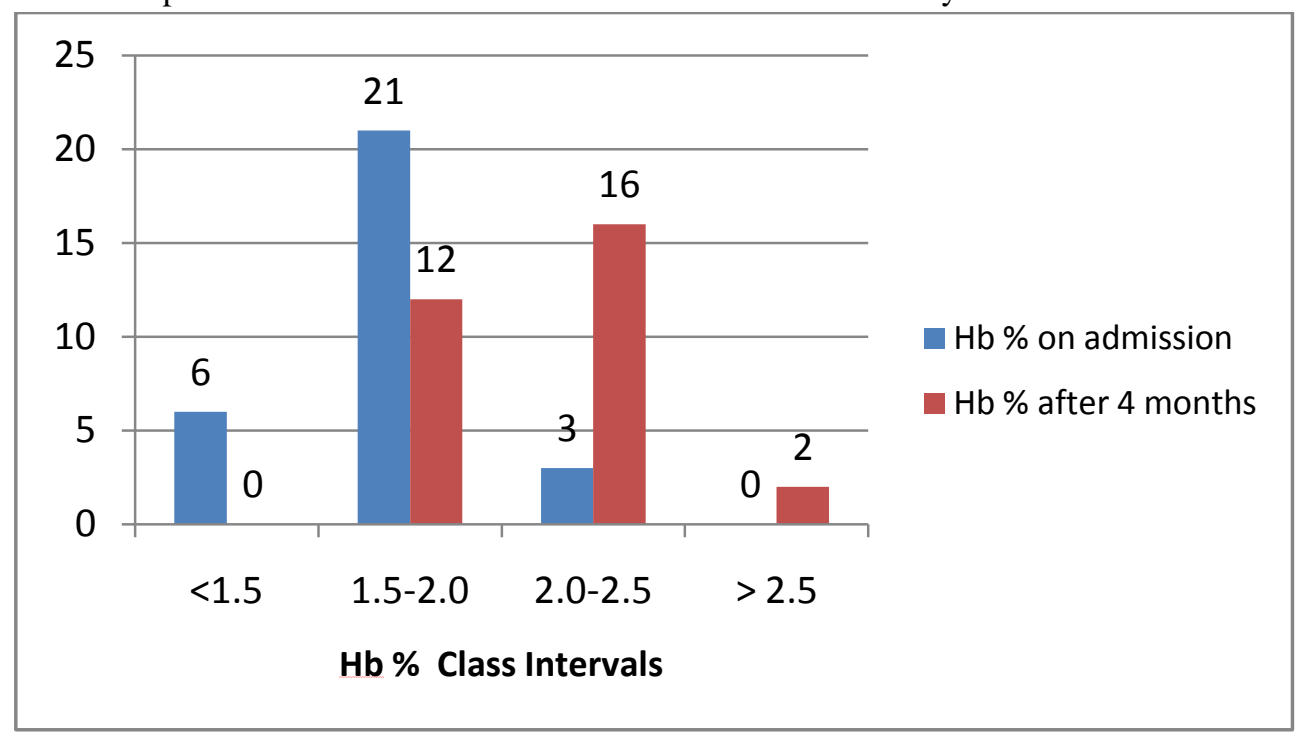

III) Parameters of paired 't' test: (Female beneficiary)
1. Sample size (n)
$=20$
2. Mean difference
$=-0.3825$
3. Standard deviation
$=0.05199$
4. Standard Error
$=0.011$
5. t value
$=-32.8806$
6. P value
$=\mathrm{P}<0.0001$
7. Degrees of freedom $=19$
8. $95 \%$ confidence intervals $=-0.406779$ to -0.358221

Table No 3 Distribution $\mathrm{Hb} \%$ levels in female subjects $(\mathrm{n}=20)$

\begin{tabular}{|cc|l|l|}
\hline Hb \% Class Interval & Hb \% On admission & Hb \% After 4 months \\
\hline $5 . \quad 1.5$ & 05 & 00 \\
& & $(25.00)$ & $(0.00)$ \\
\hline 6. & $1.5-2.0$ & 14 & 10 \\
& $(7000)$ & $(50.00)$ \\
\hline $7 . \quad 2.0-2.5$ & 01 & 10 \\
& $(05.00)$ & $(50.00)$ \\
\hline $8 . \quad>2.5$ & 00 & 00 \\
& $(0.00)$ & $(0.00)$ \\
\hline Total & 20 & 20 \\
& $(100.0)$ & $(100.0)$ \\
\hline
\end{tabular}

- It is observed that $45 \%$ of benefices had shown increase in $\mathrm{Hb} \% \mathbf{2 . 0}-\mathbf{2 . 5}$. 
Fig-3 Comparisson in HbF Levels Before and After 4 Months of Hydroxurea in Females

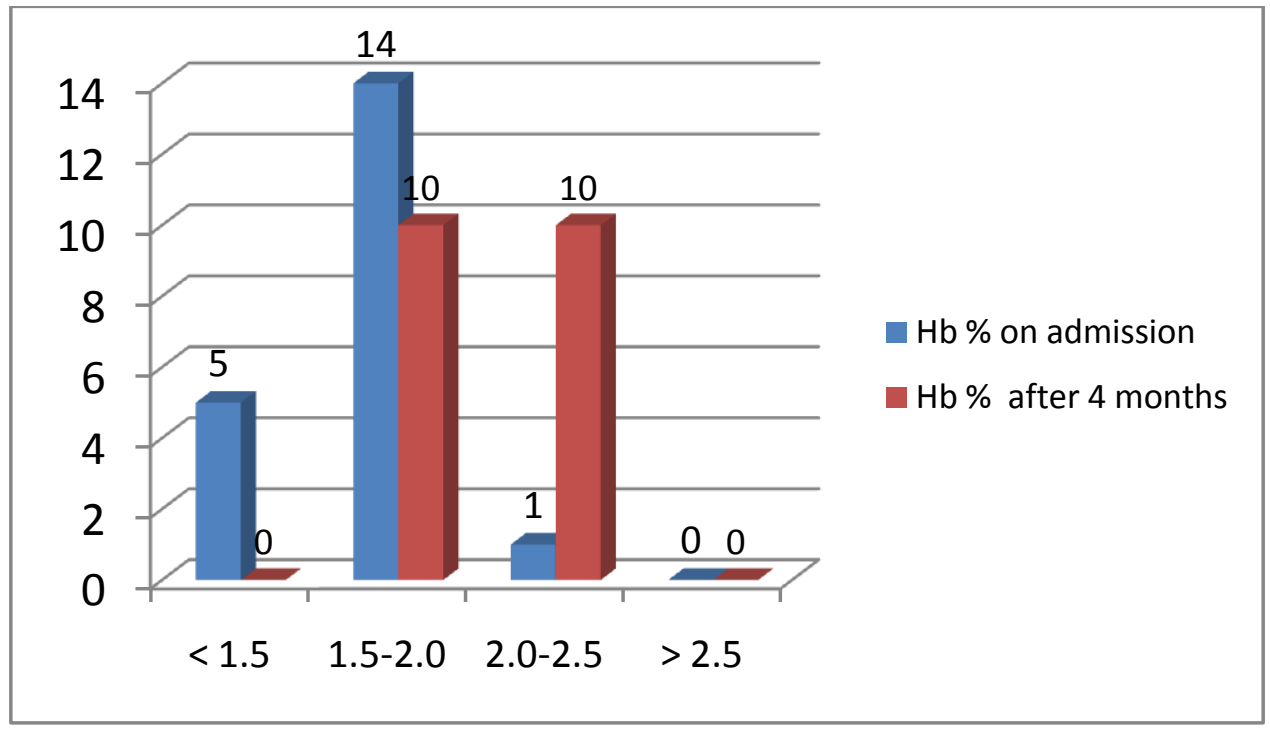

\section{Observation And Discussion}

The Mean difference in HbF was -0.3979 with SDof 0.0663 and $\mathrm{p}$ value ,0.0001.In males $(\mathrm{n}=30)$ the mean difference was -0.4087 with SD of 0.025 and $\mathrm{p}$ value $<0.0001$.I $\mathrm{n}$ females the mean difference was 0.3825 with SD 0.05199 and $\mathrm{p}$ value $<0.0001$.There was a previous study by Veith etal ${ }^{9}$.A study by Timson revealed similar findings ${ }^{10}$. CharacheS,DoverGJ etal published similar findings in their study ${ }^{11}$. Rodgers etal in his study Hematologic responses of patients with sickle cell disease to treatment with hydroxyurea showed similar findings ${ }^{12}$

\section{Conclusion}

There is significant increase (20-25\%) of HbF levels after administration of hydroxyurea in Sickle Cell Disease patients. There is significant decrease in mortality after usage of hydroxyurea in Sickle cell desease patients. There is overall improvement in well being of patients of sickle cell disease after usage of hydroxyurea.

\section{Bibiliography}

[1]. Dacie JV. The haemolytic anaemias: congenital and acquired. Part I -- the congenital anaemias. 2nd ed. New York: Grune \& Stratton, 1960

[2]. Diggs LM. Anatomic lesions in sickle cell disease. In: Abramson H, Bertles JF, Wethers DL, eds. Sickle cell disease: diagnosis, management, education, and research. St. Louis: C.V. Mosby, 1973:189-229.

[3]. Robert K Murray,David ARenda,Kathleen M Botham,Peter J kennelly,Victor W Rodwell,P.Anthony Weil:Harpers Illustrated Biochemistry:28 ${ }^{\text {th }}$ Edition:2011:Chapter37:Pg357

[4]. Stephen J Mc Phee,Maxine APapadakis,Micheal W Rabow,Current Medical Diagnosis And Treatment(CMDT),51 Editin,2012,Chapter13,Pg487

[5]. Orah S. Platt, M.D., Bruce D. Thorington, M.S., Donald J. Brambilla, Ph.D., Paul F. Milner, M.D., Wendell F. Rosse, M.D., Elliott Vichinsky, M.D., and Thomas R. Kinney, M.D.N Engl J Med 1991; 325:11-16

[6]. Robert K Murray,David ARenda,Kathleen M Botham,Peter J kennelly,Victor W Rodwell,P.Anthony Weil:Harpers Illustrated Biochemistry:28 ${ }^{\text {th }}$ Edition:2011:Chapter6:Pg46.

[7]. Stephen J Mc Phee,Maxine APapadakis,Micheal W Rabow,Current Medical Diagnosis And Treatment(CMDT),51 Editin,2012,Chapter13,Pg1607(t)

[8]. Robert K Murray,David ARenda,Kathleen M Botham,Peter J kennelly,Victor W Rodwell,P.Anthony Weil:Harpers Illustrated Biochemistry:28 ${ }^{\text {th }}$ Edition:2011:Chapter50:Pg566

[9]. Veith R, Galanello R, Papayannopoulou T, Stamatoyannopo- ulos G: Stimulation of F-cell production in patients with sickle-cell anemia treated with cytarabine or hydroxyurea. N Engl J Med 313:1571,1984

[10]. Timson J: Hydroxyurea. Mutat Res 32115,1975

[11]. Charache S, Dover GJ, Moyer MA, Moore JW: Hydroxyurea- induced augmentation of fetal hemoglobin production in patients with sickle cell anemia. Blood 69:109,1987

[12]. Rodgers GP, Dover GJ,Noguchi CT, Schechter AN, Nien- huis AW Hematologicresponses of patients with sickle cell di- sease to treatment with hydroxyurea. N Engl J Med 322:1037,1990 